\title{
ローレンツカ駆動による放電スイツチとその特性
}

$$
\begin{aligned}
& \text { 正員茾上訓一（指月電機） } \\
& \text { 正員長谷川三雄（国土舘大学） } \\
& \text { 正員上堌勛黃 (東京大学大学院) }
\end{aligned}
$$

\author{
Discharge Switch Driving by Lorentz Force \\ and Its Characteristics \\ $\begin{array}{ll}\text { Kunikazu Inoue } & (\text { Shizuki Electric Co., Inc.) } \\ \text { Mitsuo Hasegawa } & \text { ( Kokushikan University ) } \\ \text { Isao Ueno } & \text { (University of Tokyo) }\end{array}$
}

Our newly developed "Rotary-Arc mode Discharge Switch" have featured longer life expectancy and lower inductance-wise by extremely minimizing the insulation deterioration and consumable main electrode through installation of permanent magnet, simplified construction and careful attention on the demagnetization. Resultantly, highly efficient and larger capacitive discharge switch have been available at such economical cost.

In addition, by having derived an experimental formula for the driving speed of the arc, the required design parameters of the discharge switch have been determined, and then it has been well noted that any affections of electro-magnetic Lorentz force toward the starting characteristics have been negligible small.

All these have made it possible to materialize such discharge switch which will satisfy the required conditions.

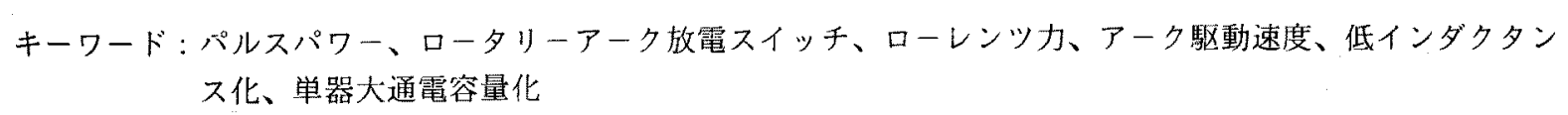

1.はじめに

核融合研究の進展に伴い、プラズマの長時間保持用と、 その容器の放電洗浄用、亚びに、誘導性エネルギー苗樍方 式を用いた様々な形式の装置用い)電源に対しては、低速 放電用大通電容量ギャップスイッチの開発が必要とされて いる。蓄積されたエネルギーを急速に負荷へ供給するパル スパワーシステムに於いて、投入スイッチ、転送スイッチ、 並びに、遮断スイッチの特性が、システム全体におよぼす 影響は極めて大きく、それらのスイッチの高速性、実用性、 容量性等に関する性能の改善が絶えず要求される。 従来の放電ギャップスイッチは、アーク路が固定され、
主電極の偏消耗が著しく、大通電容量スイッチとしての寿 命を延ばすためのアーク駆動源として、コイルを用いる方 式等が採用されてきたが、これによりコイルの通電容量、 電磁機械力等の制約を受け、構造が複雑化するとともに、 インダタタンスの増大は免れなかった。

著者等はこれらの問題点の一部を解決すべく、永久磁石 駆動方式によるロータリーアーク放電を活用した、長寿命 でかつ極めて構造の簡単なスイッチを開発し、これを誘導 性エネルギー蓄積電源用の低速放電単器大通電容量（60

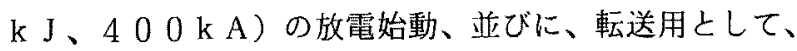
特にプラズマフォーカス用電源に活用 (2) してきているの で、このスイッチ自体の着想とその性能については報告を 
してきている(3) 〜14)。

本論文はこの方式のスイッチ、ロータリーアーク放電ス イッチのさらなる活用と応用開発、例えば、本スイッチの 電鉄変電所用直列コンデンサの過電圧保護装置等への適用 に対して、その基本特性を調査したので報告する。

\section{2. 放電スイッチに要求される条件}

\section{（1）始動特性の安定性}

放電スイッチは、負荷の条件に合わせて、高速夕イムシ 一ケンス制御を要求される場合が多く、始動指令に対する 始動遅れ、および、始動バラツキ等の始動特性はn s e c のオーダであるため、その安定性が要求される。

\section{（2）電極表面の損傷抑制}

放電スイッチは主電極間の絶縁破壊電圧以下の電压で充 電し、始動指令をトリガ電圧で印加して、主電極間の絶縁 破壊を高速で導き、始動する方式が一般的である。

従って、放電回数の増加とともに電極表面の損傷が激し い場合は、絶縁破壊電厈が低下し、トリガ篦圧を印加する 前に不要動作を生じたり、始動特性が少化して安定した制 御が不可能になるため、電極表面の損第を極力抑制するこ とが要求される。

（3）主電極間絶縁物の劣化㧕制

アークによる主電極間絶縁物の絶縁出化を抑制するため に、主電極間のアークを主電極間の対向空間内に閉じ込め ることが要求される。

\section{(4) その他の条件}

エネルギーの転送効率を高めるための低インダタタンス 化の他、単器大通電容量化、長寿命化、メンテナンスフリ 一化が要求される。

\section{3.スイッチの構造とその動作原理}

〈3・1〉構造 図1（a）はロータリーアーク放 電スイッチの構造を示しており、図1（b）はA-A' 線 分で切断したトロイダル形状主電極の断面を示す。主電極 1 亡2 は内径 $17 \mathrm{~mm}$ 、外径 $54 \mathrm{~mm}$ 黄銅製卜ロイダル 形状で、その間隔は $3 \mathrm{~mm}$ に調整し、トリガ電極は厚さ 1 $\mathrm{mm}$ 、直径 $24 \mathrm{~mm}$ 端面を半径 $0.5 \mathrm{~m} \mathrm{~m}$ に仕上げた銅

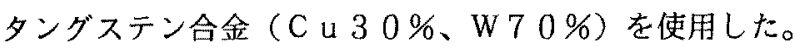

トロイダル形状主電極 1 と 2 の間には、この電極内に装 着した永久磁石 4 により、放電電流 $\mathrm{i}_{3}$ と直交する磁束 $\phi$ が与えられる。永久磁石の減磁防止に対して、永久磁石は 電流 $\mathrm{i}$ 3によって生じる磁束と鎖交しないよう主電極に囲 まれて配置されている。

本試験に用いたスイッチは、ロータリーアークスイッチ の基本特性を测定することを目的として設計しており、主 電極のフランジ間を 4 本の絶縁棒で固定し、気中開放形よ した。従って、4 章に記述する試験は常温常压の大気中で 行い、放電毎に压縮乾燥空気等による主電極間の洗浄は行
わない、極めて単純な構造とした。

〈3・2〉動作原理 ロータリーアーク放電スイッ チの動作原理 ${ }^{(15)}$ は、主電極内に装着した永久磁石により、 アーク路上直交する磁界を作り、この磁界亡放電電流との 間に㗢く電磁ローレンツカでアークを駆動する。アーク路 は高速で移動するため、自力消弧性能を持ち、かつ電極消 耗が少なく、放電が安定している。

図 1 （a）に示すトリガ電極 3 にパルス電圧が盯加され、 主電極間が図 1 (b) に示す P 点で放電を開始すると、i ヶは 面を回転運動する。

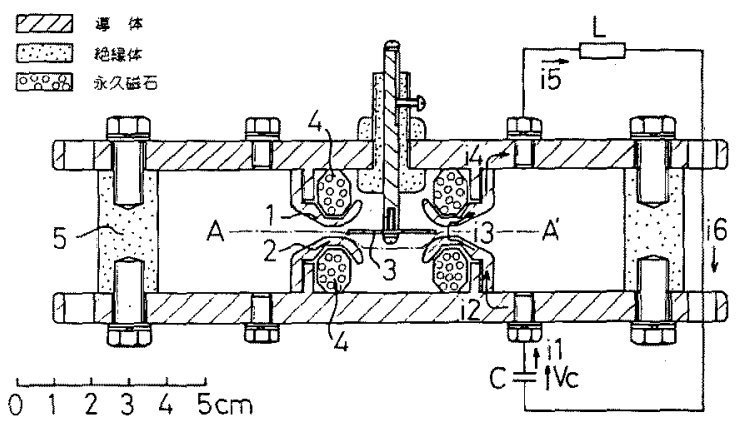

1. 負荷側主電極 2. 電源側主電極

3. トリガ電極 4. 永久磁石 5. 絶縁チェンバー

図1（a）スイッチの構造

Fig. 1(a). The structure of switch.

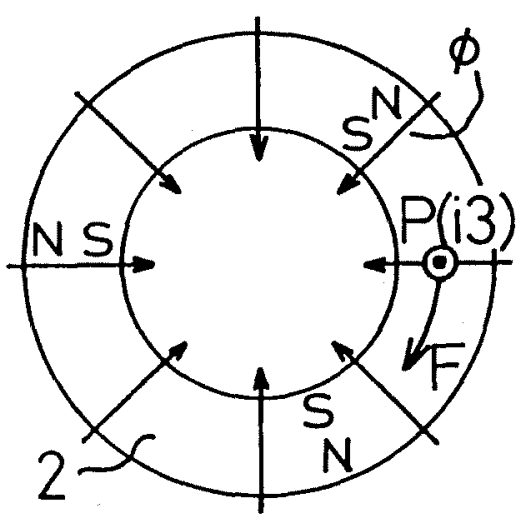

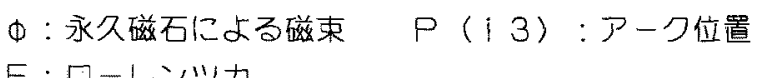

F : Qーレンツカ

図1 (b) 主電極のA-A'線分断面

Fig. 1(b). Sectional plan for $A-A$ of main electrode. 図1ロータリーアーつ放電スイッチの構造と動作原理

Fig. 1 The structure and operating principle for Rotary-Arc discharge switch. 
従って、アーク路、並びに、そのスポットは絶えず移動 するため、主電極の対向面は均一に消耗し、しかもアーク は軌道をそれないため、放電ギャップ空間の絶縁物 5 に触 れることがないので、絶縁劣化が緩和される。

\section{4. 試殹}

$\langle 4 \cdot 1\rangle$ 主電極間の磁束密度分布 主電極内に装 着したトロイダル形状のストロンチウムフェライト永久磁 石による、主電極間の磁束密度分布をガウスメータで測定 した結果を図 2 に示す。図中の実線は放電寿命試験前の主 電極間の磁束密度分布を示し、破線は5000 回の放電寿 命試験後の磁束密度分布を示している。図 2 より、放電寿 命試験前と 5000 回の放電寿命試験後の磁束密度分布に は殆ど変化がなく、安定した磁束密度分布を維持している ことを検証した。

\section{$\langle 4 \cdot 2\rangle$ 始動特性}

(1) 目的

ロータリーアーク放電スイッチは、主電極内に永久磁石 を装着して、その電磁ローレンツカでアークを駆動する。 装着した永久磁石に起因して主電極間に発生する磁束が、 ロータリーアーク放電スイッチの始動特性に与える影響を 調べるため、図 3 に示す測定回路により、ロータリーアー

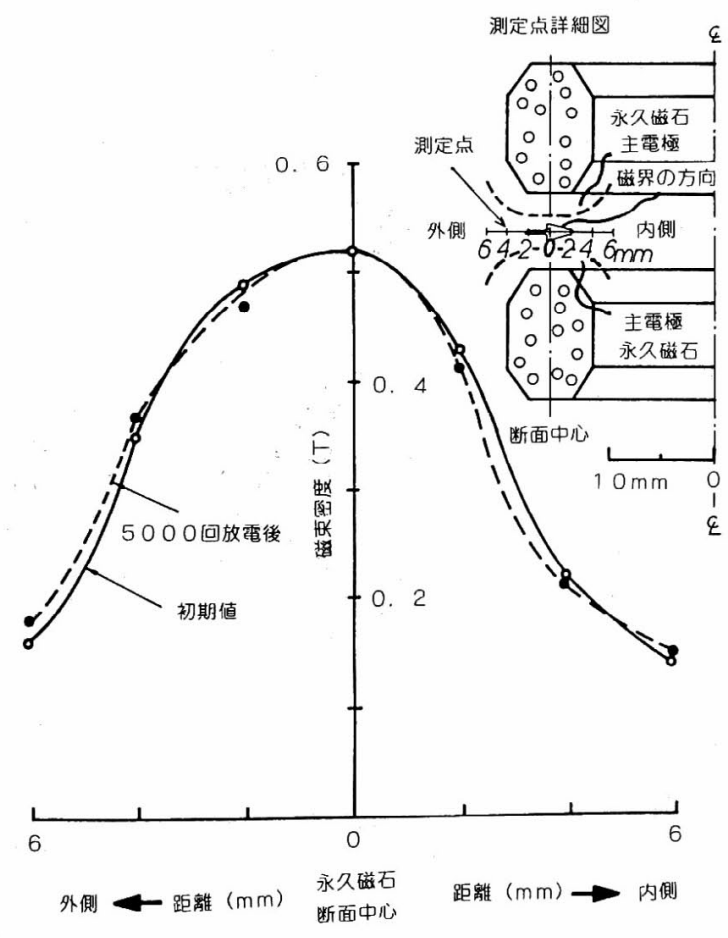

図2 主電極間の磁束密度分布

(ギャツプ間隔：3 $\mathrm{mm}$ )

Fig. 2. The magnetic flux density distribution between main electrode.

( Gap space : $3 \mathrm{~mm}$ )
ク放電スイッチの始動特性を測定した。

(2) 方法

始動遅れと始動バラッキを正確に測定するため、図 3 に 示す测定用ケーブル $\mathrm{l}_{1}$ と $\mathrm{l}_{2}$ の長さを等しくし、测定ケ

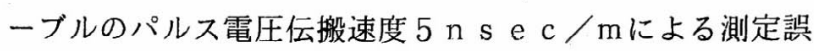
差をなくす方法を採用した。

始動特性の試験方法は、静電容量 2.2 $2 \mu \mathrm{F}$ の電源用コ ンデンサを用い、トリガ方式としてー10 k Vのパルス発 生器 P Gを 1 対 2 のパルストランスを経て、ディカップリ ング用コンデンサとして静電容量 6000 p F のセラミッ クコンデンサを介し、トリガ電極へ印加する電界歪形トリ ガ方式を採用した。負荷コイルは $300 \mu \mathrm{H}$ の空心コイル

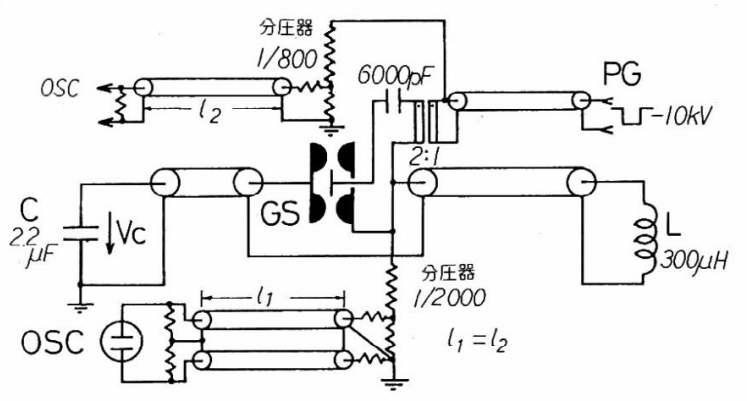

OSC : オシロスコープ PG：パルス発生器

図3 始動特性の測定回路

Fig. 3. The measurement circuit for starting characteristic.

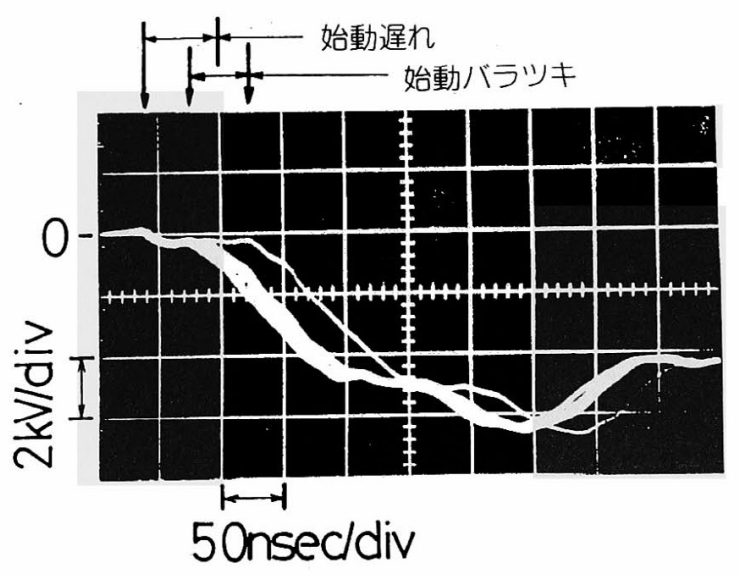

永久磁石：あり 過電圧率：56\% 主電極間充電電圧 $V_{c} ： 5 \mathrm{kV}$

図4 始動特性の実測例

Fig. 4. The measurement result for starting characteristic. 
を使用した。

始動特性の測定は、過電圧率＝（主電極間充電電圧／主 電極間絶緣破壊電压） $\times 100 （ \%)$ と主電極間充電電圧 (コンデンサ充電電圧) をパラメータとして、各パラメー タに 50 回の放電試験を行い、一枚のオシログラムに重ね 撮りをして、このオシログラムより始動遅れと始動バラッ キを読みとる方法を採用した。

(3) 結果

図4のオシログラムは、永久磁石を装着した場合に、過 電圧率を $56 \%$ 、主電極間允電電圧を $5 \mathrm{k} \mathrm{V}$ とする、始動 特性の実測例を示す。永久磁石の装着有無による始動遅れ、 始動バラツキ、過電圧率および主電極間充電電圧の関係を 図 5 に示す。

始動遅れの定義は、トリガ電極と何れか一方の主電極間 が放電してから、主電極間が放電するまでの時間とし、各 パラメータの 50 回の放電試験の平均值で示した。始動バ ラツキは、始動遅れの最大値から最小值を差し引いた時間 で示した。

\section{〈4・3〉 アーク駆動速度の测定}

(1) 目的

試験の目的は、電磁ローレンツ力駆動によるアーク駆動 速度 $\mathrm{v}$ の実験式を、主電極間の磁束密度 $\mathrm{B}$ と放電電流 I の 関数として導出し、放電電流に対する主電極のトロイダル 直径、および、主電極間の磁束密度の適正な選定を可能に することである。

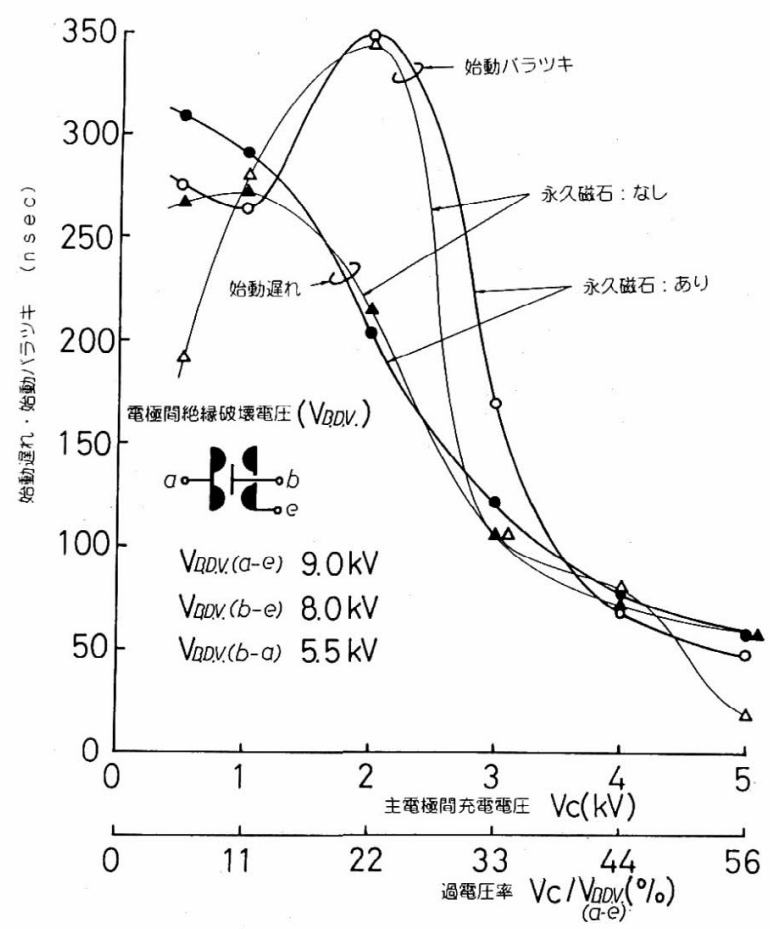

図 5 永久磁石の装着有無による始動特性

Fig. 5. The starting characteristic for switch equipped with or without permanent magnet.

\section{(2) 方法}

アーク駆動速度の測定回路を図 6 に示す。図中の負荷イ ンダクタンスは $80 \mu \mathrm{H}$ を使用した。高速シーケンス制御 盤H S S Cにより、オシロスコープO S C、放電スイッチ G S 、イメージコンバータカメラ I C C を順次トリガし、 イメージコンバータカメラによりアークの流し撮りを 70 $\mu \mathrm{s}$ e c 行い、アーク軌跡よりアークの回転角 $\theta$ ( $\mathrm{r}$ a d )

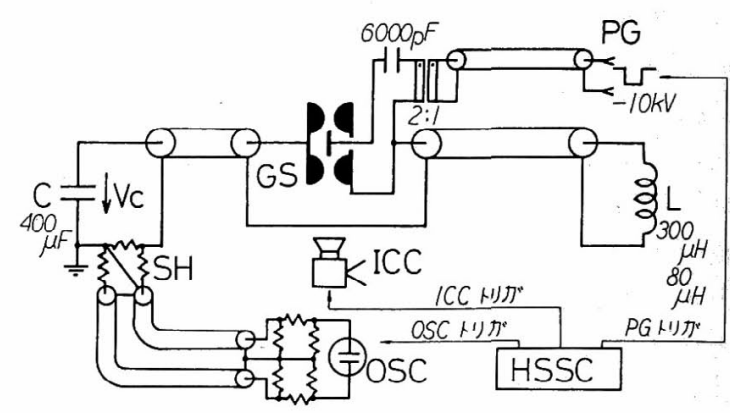

HSSC : 高速シーケンス制御盤 I C C : イメージコンバータカメラ $\mathrm{SH}$ : 同軸シャント

図6アーつ駆動速度の測定回路

Fig. 6. The measurement circuit for arc driving velocity.

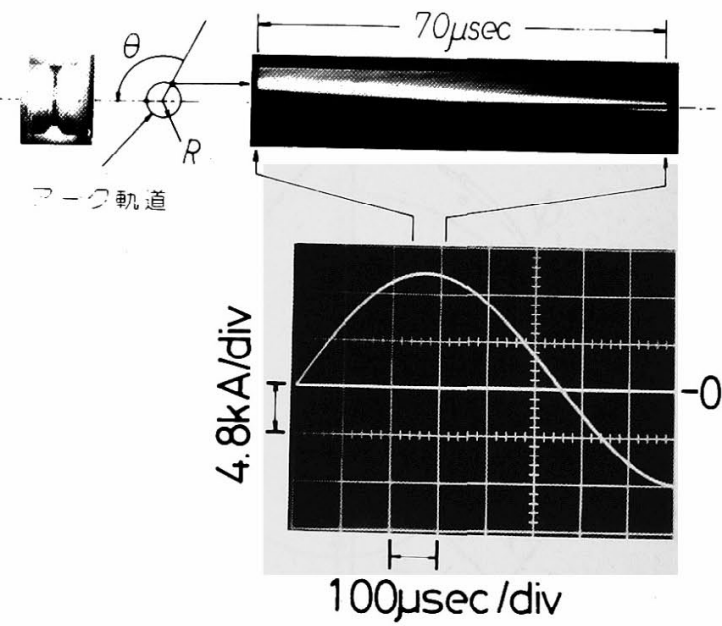

$$
\begin{aligned}
& \theta: P ー フ \text { 回転角 } 0.66 \pi(r \text { a } d) \\
& \mathrm{R}: \text { Pーク回転半径 } 16 \mathrm{~mm} \\
& v=(\theta R) / 70 \\
& =0.47(\mathrm{~mm} / \mu \mathrm{sec}) \\
& =470 \quad(\mathrm{~mm} / \mathrm{msec})
\end{aligned}
$$

図7アーつ駆動速度の実測例

Fig. 7. The measurement result for arc driving velocity. 
を求め、回転角 $\theta$ とアーク回転半径 Rより、アーク駆動長 を求め、アーク駆動速度の実験式を導出した。

(3) 結果

図7はアーク駆動速度の実測例を示す。図 7 の上段の写 真は、イメージコンバータカメラによる70 70 s e c の流 し撮りの写真を示す。その左は同じく同位置よりイメージ コンバータカメラでコマ撮りした放電スイッチの主電極部 の写真とアーク軌道の模式図を示す。イメージコンバータ カメラによる流し撮りの写真は、始動スイッチを投入して から240 $4 \mathrm{~s}$ e c 後に流し撮りの撮影を開始し、アーク の軌跡を $70 \mu \mathrm{s} \mathrm{e} \mathrm{c}$ 間流し撮り撮影をした結果である。

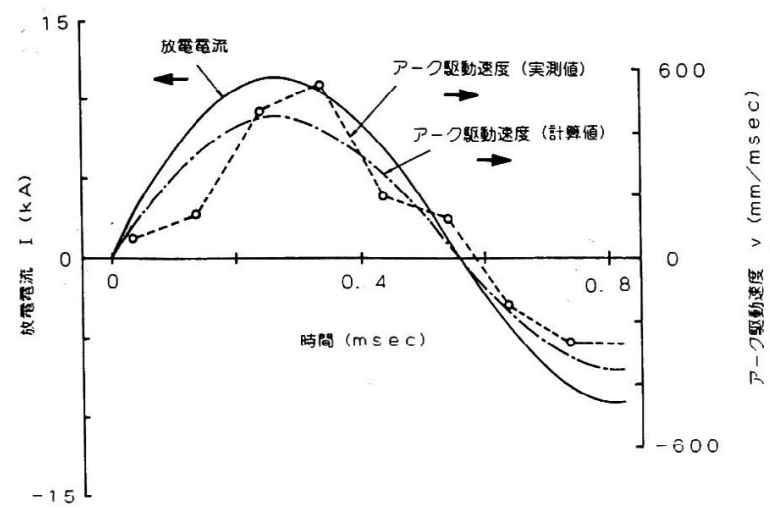

図8 放電電流波形とアーつ駆動速度の関係

Fig. 8. The relation between discharge current waveform and arc driving velocity.

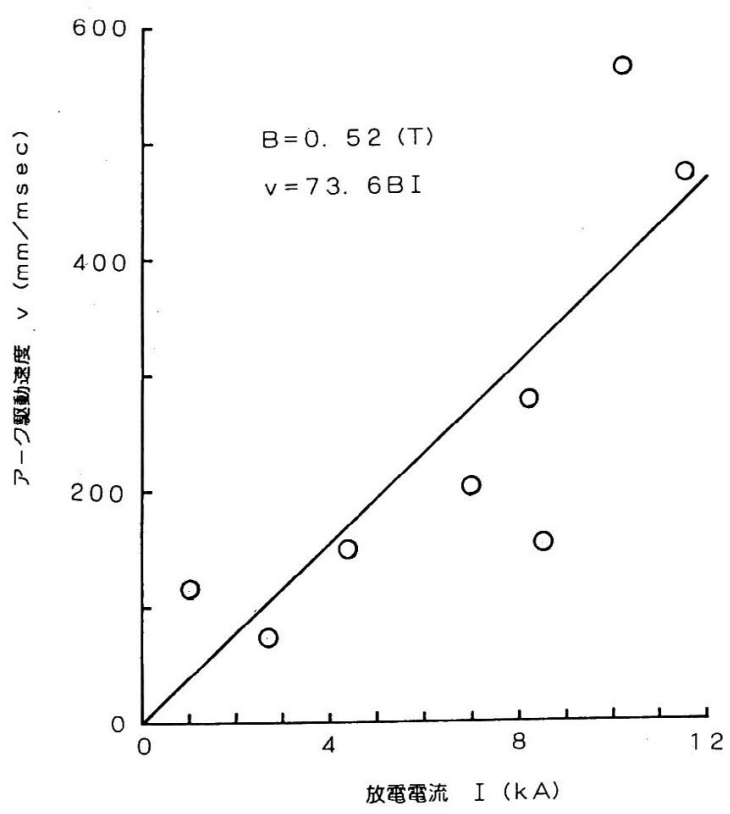

図 9 放電電流とアーつ駆動速度の関係

Fig. 9. The relation between discharge current and arc driving velocity.
流し撮り写真のアークの起点は、アーク軌道の模式図に示 す回転角 $\theta$ を表す矢印であり、 $\theta$ の角度は紙面手前から奥 に向かって70 0 s e c で回転したことを示す。

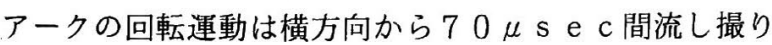
をしており、その観測内容は正弦波状アーク軌跡の一部分 になる。アークの回転角 $\theta$ とアークの回転半径 R は、流し 撮り写真 $70 \mu \mathrm{s}$ e c 問の起点と終点で、その手法は主電 極写真の電極位置より求めた。従って、アーク駆動速度 $\mathrm{v}$

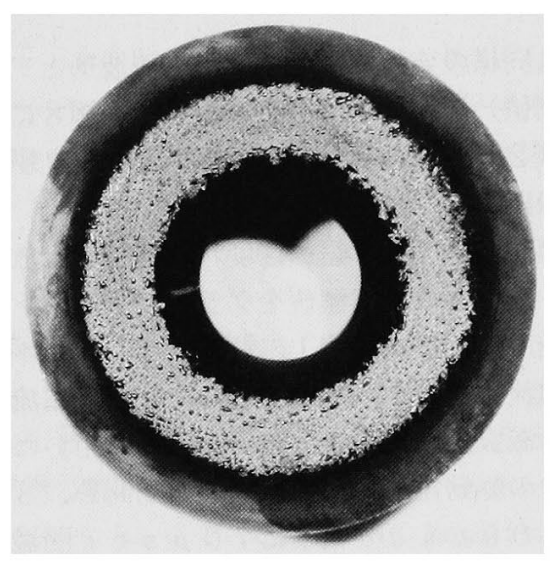

図 10 (a) 永久磁石装着 (放電回数：5000回)

Fig. 10(a). There were equipped with permanent magnet.

(discharged : 5000 times)

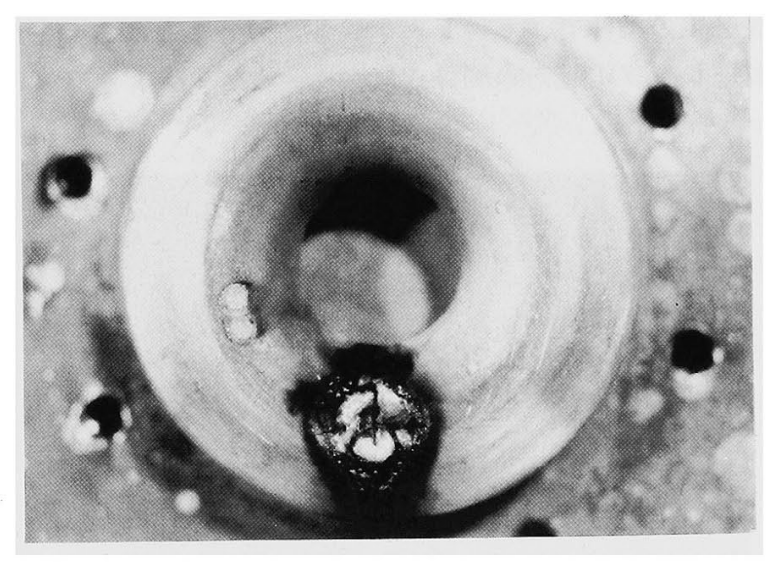

図10（b）永久磁石末装着 (放電回数 : 1 回)

Fig.10(b). There were equipped without permanent magnet.

( discharged: 1 time )

図10 放電繰返し後の黄銅製主電極表面

Fig. 10. The surface with main electrode of brass made after repeated discharge. 
は、 $\theta \mathrm{R}$ からアークの駆動長を求め、（1）式にアーク撮 影の流し撮り時間 $\mathrm{t}=70 \mu \mathrm{s}$ e c を入れると求まる。

$$
\begin{aligned}
\mathrm{v} & =(\theta \mathrm{R} / \mathrm{t}) \\
& =(0.66 \pi \times 16) / 70 \\
& =0.47 \quad(\mathrm{~mm} / \mu \mathrm{s} \mathrm{e} \mathrm{c}) \\
& =470 \quad(\mathrm{~mm} / \mathrm{m} \mathrm{se} \mathrm{c})
\end{aligned}
$$$$
\text { ・.・ (1) }
$$

この時の放電電流 I は $70 \mu \mathrm{s}$ e $\mathrm{c}$ 間の平均値として 1

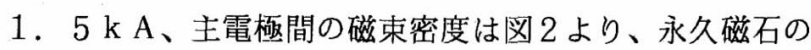
断面中心部 (半径 $\mathrm{R}=16 \mathrm{~mm}$ ) の值を取り $0.52 \mathrm{~T}$ で ある。

図 8 は同様の方法で求めた放電電流波形とアーク駆動速 度 (実測値) の関係を示した。さらに、図8には後述する 実験式（2）から計算した放電電流とアーク駆動速度（計 算値）の関係も示した。

図 9 は図 8 のアーク駆動速度 (実測値) と放電電流の関 係より、それぞれの実測値をグラフにプロットして、アー ク駆動速度 Vと放電電流 I の関係を示した。本図の実験条 件は、電流周期が $1.1 \mathrm{~m} \mathrm{~s}$ e c で、その電流最大值が 1 $1 \mathrm{kA}$ の減衰振動波形の放電駆動電流を用いた。アーク速 度は、この駆動電流の第一半周期の期間を、8点の時刻か らほぼ $100 \mu \mathrm{s}$ e c 刻みに $70 \mu \mathrm{s}$ e c 間撮影すること から求めている。アークの駆動長は、高速度シーケンスカ メラを用いて撮影したアークの軌跡より求めてプロットを している。従って、この実測値のそれぞれの值は、同一の 放電駆動電流が流れている間の、連続した放電電流の中で の値であり、大変その意味が重いものと考える。

図9の実線は、同図の実測值をプロットし、その值を回 帰直線を求める式に代入した、その回帰直線を示す。アー ク駆動速度 $\mathrm{v}$ は図 9 の回㷌直線からは、磁束密度 $\mathrm{B}=0$. 52 Tの条件で、 $\mathrm{v}=\mathrm{k} \times \mathrm{I}=38.3 \mathrm{I}$ となる。また、 ローレンツ電磁力の関係式は、 $\mathrm{v}=\mathrm{k} \times \mathrm{I}=\mathrm{k} 。 \mathrm{~B} \times \mathrm{I}$ が

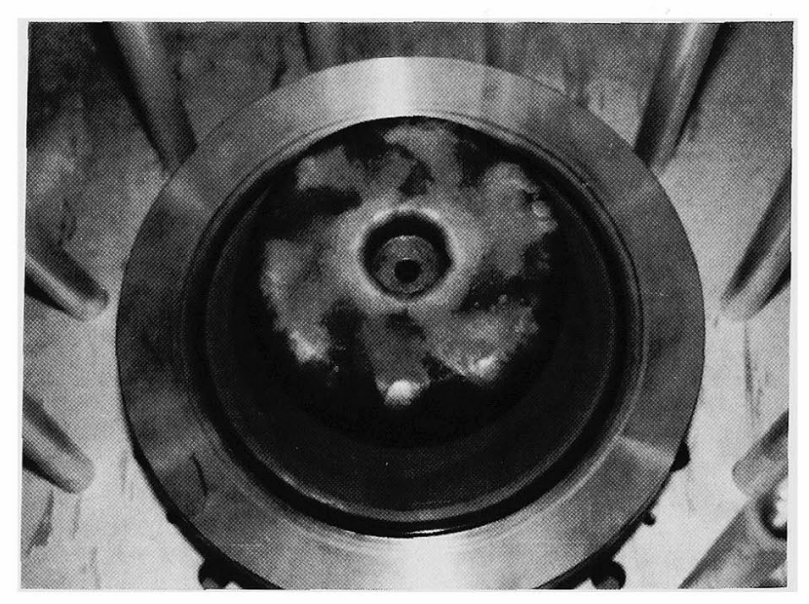

図11800回放電後の銅製主電極表面 (単器大通電容量化)

Fig. 11. The surface with main electrode of copper made after repeated discharge of 800 times ( Single larger capacitive)
成り立つので、 $\mathrm{k}$ 。を求めると、 $\mathrm{k}=\mathrm{k}$ 。 $\mathrm{B}$ より、 $\mathrm{k}_{0}=$ $\mathrm{k} / \mathrm{B}=38.3 / 0.52=73.6$ となる。従って、 アーク駆動速度 v (m m/m s e c ) の実験式は（2）式 となる。

$$
\begin{aligned}
& \mathrm{v}=73.6 \mathrm{~B} \times \mathrm{I} \\
\text { ここに } &
\end{aligned}
$$$$
\mathrm{B}: \text { 磁束密度 }(\mathrm{T})
$$$$
\text { I : 放電電流 ( } \mathrm{k} \mathrm{A} \text { ) }
$$

〈4・4〉 ローレンツ力駆動とその寿命 図1に示 すロータリーアーク放電スイッチに於いて、主電極の内径 を $17 \mathrm{~mm}$ 、外径を $54 \mathrm{~mm}$ 、磁束密度を $0.52 \mathrm{~T}$ とす る仕様で、図6に示す負荷コイルを $300 \mu \mathrm{H}$ とし、主放 電回路に最大放電電流 $5 \mathrm{k} \mathrm{A}$ 、放電電流周期 $2 \mathrm{~m} \mathrm{~s}$ e c、 通電電気量 125 (C/回) の減衰振動電流を流し、50 00 回の放電を繰返した後の黄銅製主電極の表面を汹 10

(a) に示す。

同一条件で永久磁石を装着しない場合は、図 10 (b) に示すように僅か 1 回の放電で、主電極の偏消耗が激しく、 機能を失ったのに対し、永久磁石を装着した場合の主電極 の表面は、図10（a）に示すように均一に消耗しており、 所期の性能を十分保持していることを検証した。

更に、銅製主電極の内径を $40 \mathrm{~mm}$ 、外径を $150 \mathrm{~mm}$ 、 ストロンチウムフェライト永久磁石の磁束密度を 3 . $7 \mathrm{~T}$ とするロータリーアーク放電スイッチを製作し、充電エネ ルギーを $60 \mathrm{k} \mathrm{J}$ 、最大放電電流を 200 〜 $00 \mathrm{k} \mathrm{A}$ 、

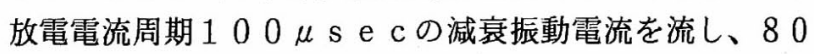
0 回の放電を繰返したが、図 11 に示すように所期の性能 を十分保持して稼働しており、ロータリーアーク放電スイ ッチの単器大通電容量化を可能にした。

\section{$\langle 4 \cdot 5\rangle$ 考察}

(1) 放電メカニズムとそのモード

図 5 に示すトリガ電極 $\mathrm{b}$ と電源側主電極 $\mathrm{a}$ 、負荷側主電 極 e との間の絶縁破壊電圧は、トリガ電極をそれぞれ 5.

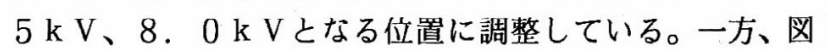
3 に示す電源コンデンサC は負に充電をしているので、電 源側主電極は充電中ー $V_{c}$ の電位となり、負荷側主電極 $\mathrm{e}$ は負荷コイルを経て接地されているため、常時アース電位 となる。従って、トリガパルスはー10 k Vのパルスをパ ルストランス巻数比 1 対 2 で昇圧し、トリガ電圧最大值一 $20 \mathrm{k} \mathrm{V}$ が負荷側主電極 e とトリガ電極間に印加される。 主電極間が放電するメカニズムはトリガ電極の電位がー2 $0 \mathrm{kVV}$ に立ち上がる過程で、電源側または負荷側の何れか の主電極に放電し、その火花効果と各ギャップ間の急変す る電界を採用している。

本実験では、トリガ電極と主電極間のトリガ放電モード は、 $V_{C}$ が高い場合はトリガが負荷側主電極 $\mathrm{e}$ へ放電する ように、トリガ電極と主電極間の絶縁破壊電圧を調整して いる。トリガ時でのトリガ電極と電源側主電極間に発生す る電位差は、主電極 $\mathrm{a}$ の電圧 $\left(-\mathrm{V}_{\mathrm{C}}\right)$ とトリガ電極の電 圧 $\left(-V_{T}\right)$ から $\left|V_{T}-V_{C}\right|$ となる。主電極 $\mathrm{e}$ とトリ 
ガ電極間の電位差は、主電極 $\mathrm{e}$ の電位が $0 \mathrm{Vであるので、}$ $\left|V_{T}\right|$ となり、放電はそれぞれの過電王率の高い方へ先 行する。

（2）始動バラツキ

始動バラツキは、主電極間の充電電圧が $2 \mathrm{kV}$ より低い 領域で減少しているが、始動バラツキは $2 \mathrm{kV}$ で最も大き い。この時の過電圧率は2つのモードがほぼ等しく、また、 始動バラッキは過電压率が低くなるために大きくなる。主 電極間の充電電圧が $2 \mathrm{k} \mathrm{V}$ を回ると、トリガ放電モード は電源側の主電極が先行する放電モードとなる。従って、 トリガ電流は電源㑡の主電極からコンデンサC、アース経 由で負荷コイルL、負荷側の主電極への経路で流れる。そ して、電生発生は急峻なトリガパルス電流に依存して、L (d i $/ \mathrm{d} \mathrm{t}$ ) による電圧が負荷コイルLに誘起される。 これにより負荷側の主電極の電位は $+\mathrm{L}(\mathrm{d} i / \mathrm{d} t) に$ 昇位され、このプロセスでトリガ電極と負荷側の主電極間 に電位差が発生し、始動バラツキは逆に小さくなると考察 する。この始動特性は電界歪形トリガ方式の特徵であり、 主電極間の過電圧率が $44 \%$ 以上領域で使用すれば、始 動特性が安定しており、実用上の支障はなにもなかった。

結果は、亚列運転の少ない高電圧大電流低速放電用の始 動スイッチとして開発した機能が、始動遅れと始動バラッ キの何れもが $100 \mathrm{nsec}$ 以下となり、十分满足してい ることを検証した。そして、永久磁石の装着による磁界が 始動特性に与える影響は、本試験の結果よりその有意差の ないことも検証できた。

\section{(3) 実験式の導出}

実験式（2）は、主電極の材料に黄銅製電極を用い、そ の主電極間に大気圧の空気を充填する場合には、一般に適 用できると推測する。これは条件が变化しても、 $\mathrm{v}=\mathrm{k} 。$ $\mathrm{B} \times \mathrm{I}$ に於いて $\mathrm{k} 。$ が変化するだけであり、一般式として 適用できる。

実験式（2）加明らかなように、放電電流の周期は、 アーク駆動速度 v 人与える影響がなく、式（2）は周期に 関係なく適用できる。但し、周期が短い場合は、放電スイ ッチの通電容量も小さく、電極損傷も極微となるため、ア 一ク駆動をあえてする必要はない。

実験式（2）の導出は、放電電流 I 、磁束密度 B および 放電電流周期から、容易に電流によるアーク駆動長を計算 によって求めるこよが可能になった。その結果、本スイッ 千設計仕様へのその具体的な効果は、通電電流の仕様に応 じた主電極のトロイダル形状半径の寸法を定量的に決定で きる等、その貢献度は大きい。

\section{5.おわりに}

著者らが開発したロータリーアーク放電スイッチの特徴 は、永久磁石を装着し、その構造を簡単にし、その減磁を 配虑し、絶縁劣化や主電極の消耗を極力軽減することによ り、長寿命化し、更に低インダクタンス化を容易にした点
にある。その結果、高効率、大通電容量の放電スイッチを 廉価に供給し得た。

更に、アーク駆動速度の実験式を導出することにより、 故電スイッ千の設計上、必要となるパラメータを定量化す るとともに、ロータリーアーク放電スイッチの基本特性を 調査し、始動特性に与える電磁ローレンッ力の影響は、無 視できるという知見を得る等、要求さ扎る条件を満足する 放電スイッチの具現化を可能にした。

（平成 10 年 3 月 25 日受付、平成 10 年 12 月 2 日再受 付)

\section{文献}

（1）上野・J.Salge -U. Braunsberger：「誘導性蓄積工 ネルギー転送用高压密閉形高速遮断素子の特性之応 用」、電学論 B、99、頁 $721-728$ (昭 54 $-11)$

（2）上野・田口：「高繰返しプラズマ・フォーカス中性 子源一誘導性エネルギ一蓄積方式電源の開発一」、 東大工核融合炬ブランケット設計基礎実験装置研究 成果報告書、頁 1 43-150（昭 5 6-6)

(3) I. Ueno, et al, : "Production of Repetitive Dense Plasmas in a Focus Device with Indutive Energy Storage " , Japanese Journal of Applied Physics, 18, pp. 1189-1190(1979-6)

(4) 1, Ueno, et al. : "Neutron Yield in a Repetitive Dense Plasma Focus ” Japanese Journal of Applied Physics , 21, pp.L746-L748(1982-12)

（5）上野、他：「誘導性エネルギ一蓄積方式による高速 立上りパルスパワー電源の開発」、電学論 B、10 2、頁1 16 （昭 $57-2$ )

（6）上野、他：「誘導性エネルギー蓄積方式による波形 制御されたパルスパワー電源の開発」、電学論 B、

102 、頁 117 (昭 $57-2$ )

（7）田口・上野、他：「誘導性エネルギー蓄積方式によ る方形波発生用パルスパワー電源の開発」、電学論 B、103、頁 223 (昭 58 - 3)

（8）田口・上野、他：「けい砂密閉形高速遮断素子の開 発」、電学論 $\mathrm{B} 、 104$ 、頁 196 (昭 $59-3$ )

（9）田口・上野、他：「誘導性エネルギー蓄積パルスパ ワーシステムの高速遮断素子制卸によるパルス整形 と形成」、電学論 B、105、頁 $925-932$ (昭6 $0-11$ )

（10）上野、他：「誘導性蓄積エネルギーによる高繰返し プラズマフォーカスの中性子発生とその比例則」、 電学論 D、107、頁 $93-100$ (昭6 2-1)

（11）田口・上野：「誘導性蓄積エネルギー転送用密閉形 高速遮断素子のア一ク消孤媒体依存性」、電学論 B、 109 、頁 $273-280$ (平元 -6 )

(12) H. Asai and I. Ueno, : "Neutron Source Based on the Repetitive Dense Plasma Focus Model" , 
Nuclear Engineering and Design / Fusion, 7 , pp. 335-343(1989)

(13) K. Inoue, I. Ueno, M. Hayashi, et al.

“ Development of Protection System Based on Pulsed Power Switching for High-Resistance Ground Fault of Power Feeding System of DC Electric Railway" , Proceeding of 9th IEEE International Pulsed Power Conference, Vol. 1. Albuquerque, New Mexico, pp. 25-28 (1993)

(14) M. Hasegawa, K. Inoue, M. Tanimoto, I. Ueno,

T. Hirai, M. Hayashi : "Development of Protective Switching Elements on Local Failures of Large Slow-Capacitor Bank System" , Proceeding of 9th IEEE International Pulsed Power Conference, Vol.2, Albuquerque,

New Mexico, pp. 739-742(1993)

（15）井上・田口・上野：「永久磁石駆動方式ロータリー アーク放電スイッ千の開発」、電学論 B、1 02 、 頁 259 (昭 $57-4$ )

井上 訓一（正員）1947年1月2日生。1974 年 3 月広島工業大学工学部電気工学科卒業。 同年 4 月（株）指月電機製作所入社。同社 中央技術研究所長、コンデンサ技術部・シ ステム技術部両部長兼務、製造部長を経て、 現在、電力機器システム技術部担当部長。

$1975 \sim 1979$ 年工業技術院電子技術 総合研究所出向。この間、大電流制御技術に関する研究に 従事。平成元年度オ一ム技術賞、科学技術長官奨励賞受賞。

長谷川三雄 （正員）1951年3月10日生。197

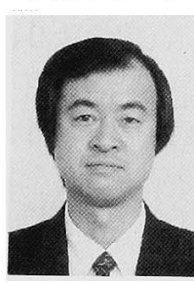
6 年 3 月日本大学大学院工学研究科電気工 学専攻修士課程修了。同年 4 月国士舘大学 教養部助手、現在、同政経学部教授。19 91 1 992 年テキサス大学オースチン 校客員研究員。この間、パルスパワー、環 境科学に関する研究に従事。I AWQ、環 境技術研究協会等会員。

上墅 勛黃 (正員) 1938 年静岡県生まれ。196

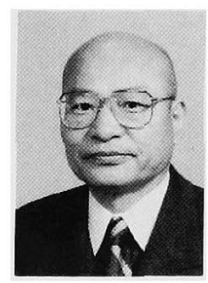
6 年明治大学大学院修了。独国州立ブラウ ンシュバイク工科大学、米国州立テキサス 工科大学等々の欧米大学、研究所の客員教 授、研究員を経歴し、現在東京大学大学院 工学系研究科 (創域科学研究系) 教官。そ の傍ら、国内ではエコシステム研究会会長、 融合サイエンスクラブ理事長、国外では国際人名センター ( I B C 本部オックスフォード) 副総裁、米国人名研究協 会（AB I R A 本部ノースカロライナ）副総裁を務める。 専門分野は地球システム科学 (生態系科学、地球環境理工
学、エコシステム経済学、エネルギー発生・変換理工学)。 工学博士。20 世紀業績賞（米国）、世界終身業績賞 (米 国）、ゴールドスター賞（英国）、等受賞。アレキサンタ 一・フォン・フンボルト財団（独国）、国際人名協会（英 国）、米国人名研究所等の終身フェロー。

"International Sash of Academia" 、"The Order of International Fellowship" 、 "International Order of Merit "等のbona fide Member。そのプロフィールは“ Who " $s$ who in the World" " "Five Hundred Leaders of Influence" 、"Dictionary of International Biography " 等、英、米国から出版されている 15 種類以 上の全世界を対象とした人名録に登録され、その献呈の辞 に記載されている。 